\title{
Comparison of Whole-Tissue and Xylem Fluid Collection Techniques to Detect Xylella fastidiosa in Grapevine and Oleander
}

\author{
Blake R. Bextine and Thomas A. Miller, Department of Entomology, University of California, Riverside 92521
}

\begin{abstract}
Bextine, B. R., and Miller, T. A. 2004. Comparison of whole-tissue and xylem fluid collection techniques to detect Xylella fastidiosa in grapevine and oleander. Plant Dis. 88:600-604.

Xylella fastidiosa is the xylem-limited bacterium that causes Pierce's disease of grapevine and oleander leaf scorch. Detection of this pathogen prior to symptom development is critical for improved management of the disease. Enzyme-linked immunosorbent assay (ELISA) and polymerase chain reaction (PCR) currently are used for routine detection of the pathogen; however, both detection methods are limited by low titer or patchy distribution of the bacterium within a host plant. In the study reported here, we directly compared $X$. fastidiosa detection in wholetissue samples with xylem fluid samples from grapevine and oleander. Collection of xylem fluid samples improved sensitivity of pathogen detection by ELISA (41.0\%) compared with wholetissue samples $(20.5 \%)$ in asymptomatic grapevine. Additionally, pathogen detection in asymptomatic grapevine by PCR also was improved when xylem samples were tested $(66.7 \%)$ compared with whole-tissue samples $(23.1 \%)$. There were no differences in frequency of detection of $X$. fastidiosa in symptomatic grapevines by ELISA or PCR dependent upon sample collection method. Assays of xylem fluid samples did not improve detection of $X$. fastidiosa in symptomatic or asymptomatic oleander compared with assays of whole tissue. Finally, in a direct comparison of ELISA and PCR, we found no significant differences in frequencies of positive grapevine or oleander samples detected.
\end{abstract}

The xylem-limited bacterium, Xylella fastidiosa, causes several economically important plant diseases, including Pierce's disease of grape (15) and oleander leaf scorch (32). Disease is caused when the pathogen interrupts the translocation of water and nutrients through the xylem of infected plants $(9,28,30)$. Symptoms of these diseases include mottled chlorosis, reduced leaf size, stunting, margin and tip necrosis, and abnormal fruit, resulting in reduced yield, and can lead to death of infected plants within 2 years (19).

Early detection of the pathogen in infected plants before the onset of symptoms is essential to studying the etiology of the disease and controlling the pathogen. Detection methods currently used include enzyme-linked immunosorbent assay (ELISA; 3,6,23,33,34), polymerase chain reaction (PCR; 2,7,8,14,23-25,34), and culturing from infected tissue (10-12,29). Several problems still exist with these methods, mainly stemming from low titer of bacteria in samples, resulting in incon-

Corresponding author: B. Bextine

E-mail: blake.bextine@ucr.edu

This research was supported by University of California DANR Pierce's disease research program.

Accepted for publication 14 January 2004.

Publication no. D-2004-0315-03R

(C) 2004 The American Phytopathological Society sistent detection $(7,8,23,25,33,34)$. The most common method used to extract the bacteria from plant tissue is crushing or grinding plant tissue (leaves, shoots, or stems). Limitations of this method include low amount of bacteria collected relative to the high amounts of plant DNA and organic matter that can interfere with ELISA or PCR. These complications can hinder detection in the early stages of disease development when the titer is low, often resulting in false negatives.

Although improvements have been made to ELISA and PCR for detection of $X$. fastidiosa, few improvements have been made to the collection of $X$. fastidiosa cells prior to the detection step. The culturing of $X$. fastidiosa from plant material prior to detection by PCR or ELISA increased the frequency of pathogen detection $(2,3,6,7,20,24,35)$. Unfortunately, this process is time consuming because $X$. fastidiosa is a slow-growing bacterium, making culturing prone to contamination. Immunoseparation also has been used to improve detection of X. fastidiosa (26); however, this system is still limited by the titer of pathogen cells recovered in sample collection.

Inadequate extraction methods hamper all detection techniques used for pathogen management and study. Improving detection of the pathogen will enhance the study of the interaction between host plants and the pathogen. A better sample-collection technique could improve the sensitivity of current detection techniques $(2,13,14,16$,
21,35). Vacuum extraction of xylem sap has been used to identify bacteria in grapevine (4). This technique allowed for concentrated amounts of xylem fluid to be collected without large amounts of plant material. In this study, we evaluate use of the Scholander pressure bomb as an improved method of xylem fluid collection from grapevine and oleander for the detection of $X$. fastidiosa.

\section{MATERIALS AND METHODS}

Scholander pressure bomb collection of xylem fluid samples. Xylem fluid was collected from cut terminals of grapevine (Vitis vinifera cv. Chardonnay) and oleander (Nerium oleander L.) plants using a Scholander pressure bomb. Terminal cuttings, approximately $15 \mathrm{~cm}$ in length, were taken from symptomatic and asymptomatic plants using sterile cutting sheers. The external layer of plant tissue containing the phloem vessels was removed using a sterile razor blade from the cut end to $2 \mathrm{~cm}$ distal (17). The removal of this tissue allowed for the collection of xylem fluid and excluded phloem fluid. The cut end of the stem was placed through the hole containing a gasket in the Scholander pressure bomb lid with approximately $3 \mathrm{~cm}$ of the cut end facing out. The foliage of the cutting was placed in the pressure chamber and the lid was locked down. When adequate pressure was applied (approximately 2,000 to $3,000 \mathrm{kPa}$ ), plant sap was forced from the tissue at the proximal end of the cutting (17). This liquid was drawn off from the exposed xylem vessels using a micropipette and placed in a $1.5-\mathrm{ml}$ microcentrifuge tube. It was important that the stem was not cut or broken and no leaves could be removed during this process because any openings in the stem would create a direct route for the pressurized air to escape, compromising the collection of fluid. In all, $100 \mu \mathrm{l}$ of xylem fluid was used directly for ELISA and $100 \mu \mathrm{l}$ was used for DNA extraction followed by PCR.

Whole-tissue collection of plant samples. For comparison, plant tissue also was collected for whole-tissue extraction. One $3-\mathrm{cm}$ sample of whole plant stem, including petioles and the main veins of attached leaves, per plant sampled was macerated in $300 \mathrm{ml}$ of phosphate-buffered saline (PBS) buffer with a mortar and pestle. In all, 100 $\mu l$ of plant extract was used directly for ELISA and $100 \mu \mathrm{l}$ was used for DNA extraction followed by PCR $(8,9,18,22,23,25$, 33,34). 
Sample collection for detection of $X$. fastidiosa in grapevine. Both whole-tissue and xylem fluid samples were collected from 30 grapevines from a commercial vineyard in Temecula, CA to be tested by ELISA and PCR on 27 August 2002 (10 visually symptomatic and 20 visually asymptomatic). An additional 30 grapevines from the University of California, Riverside campus were sampled on 23 October 2002 (11 visually symptomatic and 19 visually asymptomatic). Grapevines were observed for Pierce's disease symptoms, after which samples were taken from symptomatic and asymptomatic plants in the same vineyard by cutting the stem approximately $18 \mathrm{~cm}$ from the terminal end. From this cut terminal stem, the whole-tissue sample was taken by removing $3 \mathrm{~cm}$ of stem from the cut end and placing that $3-\mathrm{cm}$ section into a $1.5-\mathrm{ml}$ microcentrifuge tube. The remaining 15 $\mathrm{cm}$ of stem (cut end to terminal end) was used for xylem fluid collection.

Sample collection for detection of $X$. fastidiosa in oleander. Oleander plants, averaging $2 \mathrm{~m}$ in height, were assessed visually for leaf scorch symptoms prior to sampling. In cases where an infected plant had only some visually symptomatic branches, while others stems appeared healthy, the samples were taken from a branch with symptoms. Oleander samples were collected in the same way as grapevine on two dates. In all, 94 oleander plants were sampled on the University of California Riverside campus on 22 April 2002 (56 symptomatic and 38 asymptomatic). Additionally, 30 oleander samples were taken from a community adjacent to the University of California, Riverside on 8 November 2002 (15 symptomatic and 15 asymptomatic).

ELISA. A commercially available double-antibody sandwich ELISA test kit (Agdia Inc., Elkhart, IN) was used to compare detection of $X$. fastidiosa in 60 grapevine and 126 oleander whole-tissue samples to detection in xylem fluid collected from corresponding samples with the Scholander pressure bomb. ELISA was performed following the directions supplied with the kit. One hundred microliters of prepared sample was dispensed into sample wells and positive and negative controls were included. Results were evaluated by examining the wells using a Benchmark microplate reader (BioRad, Hercules, CA) and analyzed using Microplate Manager V. 5.1 build 75 software. Wells in which absorbance values at 490 nm were greater than twice that of the negative control were considered positive. Test results were valid only if positive control wells tested positive and negative control buffer wells remained clear.

DNA extraction and PCR. DNA was extracted from the xylem fluid and plant samples with a GeneClean II (GC) extraction kit (Bio 101, Vista, CA), using a pro- tocol modified from that of the manufacturer (5). Briefly, $100 \mu \mathrm{l}$ of either plant extract in PBS or $100 \mu \mathrm{l}$ of xylem fluid was mixed with $160 \mu \mathrm{l}$ of Lytic Buffer and $40 \mu \mathrm{l}$ of $5 \%$ sodium sarkosyl in a $1.5-\mathrm{ml}$ microcentrifuge tube and incubated at $55^{\circ} \mathrm{C}$ for $6 \mathrm{~min}$, followed by centrifugation $(13,200 \times g, 6 \mathrm{~min})$ to pellet cellular debris. The supernatant was transferred to the spin column with $400 \mu \mathrm{l}$ of GC Spin Glassmilk, incubated for $5 \mathrm{~min}$, and centrifuged $(10,000 \times g, 30 \mathrm{~s})$. The filter containing the silica beads and sample DNA was replaced in the catch tube and washed twice with $400 \mu$ of GC Spin New Wash. In a fresh catch tube, beads were resuspended in $100 \mu \mathrm{l}$ of GC spin elution solution, then centrifuged at $13,200 \times g$ for 1 min. The eluent, containing extracted DNA, was stored at $4^{\circ} \mathrm{C}$ until needed for PCR assays.

PCR was carried out in a $25-\mu 1$ reaction volume containing 10 to $50 \mathrm{ng}$ of genomic DNA template, $0.2 \mathrm{mM}$ each dNTP, 0.625 $\mathrm{U}$ of Taq DNA polymerase (Promega Corp., Madison, WI), and $0.2 \mu \mathrm{M}$ forward primer RT31 and reverse primer RT33 (24), in a PCR buffer (10 mM Tris- $\mathrm{HCl}$, pH 8.3, $5 \mathrm{nM}$ EDTA, $25 \mathrm{mM} \mathrm{KCl}, 4 \mathrm{mM}$ $\mathrm{MgCl}_{2}$ ). An Eppendorf Mastercycler Gradient thermocycler (Eppendorf, Hamburg, Germany) was programmed for $4 \mathrm{~min}$ at $94^{\circ} \mathrm{C}$, followed by 30 cycles of $1 \mathrm{~min}$ at $94^{\circ} \mathrm{C}, 1 \mathrm{~min}$ at 60 to $72^{\circ} \mathrm{C}$, and $1 \mathrm{~min}$ at $72^{\circ} \mathrm{C}$, with a final extension at $72^{\circ} \mathrm{C}$ for 10 min (25). A 10- $\mu$ l volume of each PCR sample was separated on a $1.2 \%$ horizontal agarose gel at $10 \mathrm{~V} / \mathrm{cm}$ for $120 \mathrm{~min}$ in TBE buffer (0.1 M Tris-HCl, pH 8.0, $0.1 \mathrm{M}$ boric acid, 2 mM EDTA). A 100-bp DNA ladder was used as a size marker. The gel was stained with ethidium bromide (0.5 $\mu \mathrm{g} / \mathrm{ml})$. A sample was considered positive for the presence of the $X$. fastidiosa if the correct DNA band was visualized using UV light.

Statistical analysis. Whole-tissue maceration was compared with xylem fluid collection using $\chi^{2}$ analysis of positive and negative ratios for symptomatic/ELISA, symptomatic/PCR, asymptomatic/ELISA, and asymptomatic/PCR combinations for each host plant on each date. Data from the two collection dates also were pooled for analysis by $\chi^{2}$. Additionally, $\chi^{2}$ analysis was used to compare ELISA and PCR as the method of $X$. fastidiosa detection in grapevine or oleander, regardless of sample collection method on separate and pooled dates.

\section{RESULTS}

Collection of xylem fluid from grapevine and oleander. Grapevine xylem fluid was relatively easy to collect with a Scholander pressure bomb and a pipette. The fluid exuded from the cut stem as a clear liquid. In contrast, the collection of xylem fluid from oleander was relatively more difficult to collect using the
Scholander pressure bomb because it exuded as froth, making collection difficult with a pipette.

Use of the Scholander pressure bomb to collect samples was more efficient than whole-tissue samples for detecting $X$. fastidiosa in asymptomatic grapevines on both dates using ELISA (replication 1: $\chi^{2}$ $=5.625, \mathrm{df}=1, P$ value $=0.025$; replication 2: $\chi^{2}=8.922, \mathrm{df}=1, P$ value $\left.=0.01\right)$ and PCR (replication 1: $\chi^{2}=4.286, \mathrm{df}=1$, $P$ value $=0.05$; replication $2: \chi^{2}=13.328$, $\mathrm{df}=1, P$ value $=0.001)$. When data from the two dates were pooled, the frequency of $X$. fastidiosa detection in xylem fluid samples of asymptomatic plants was significantly higher than the whole-tissue extract by ELISA $\left(\chi^{2}=12.045, \mathrm{df}=1, P\right.$ value $=0.0005)$ and PCR $\left(\chi^{2}=14.978, \mathrm{df}\right.$ $=1, P$ value $=0.0001)$. Based on statistical analyses of data from samples of symptomatic plants collected on both sampling dates, there were no significant differences between collection techniques in detection frequency by ELISA (replication 1: $\chi^{2}=$ $3.333, \mathrm{df}=1, P$ value $=0.10$; replication 2 : $\chi^{2}=1.692, \mathrm{df}=1, P$ value $\left.=0.20\right)$ or PCR (replication 1: $\chi^{2}=0, \mathrm{df}=1, P$ value $=1$; replication $2: \chi^{2}=3.143$, df $=1, P$ value $=$ $0.10)$. When data from the two dates were pooled, no difference was found between collection techniques in frequency of $X$. fastidiosa detection by ELISA $\left(\chi^{2}=0.099\right.$, $\mathrm{df}=1, P$ value $=0.7530)$ or $\operatorname{PCR}\left(\chi^{2}=\right.$ $1.867, \mathrm{df}=1, P$ value $=0.1718 ;$ Fig. 1$)$. In symptomatic grapevine, there was no significant difference in detection frequency between the ELISA and PCR methods of detection on either collection date (replication 1: $\chi^{2}=2.22$, $\mathrm{df}=1, P$ value $=0.136$; replication $2: \chi^{2}=0.03$, df $=1, P$ value $=$ $0.852)$ or when data were pooled $\left(\chi^{2}=\right.$ 1.35 , df $=1, P$ value $=0.245 ;$ Table 1$)$.

For oleander, use of the Scholander pressure bomb to collect samples was not more efficient than whole-tissue samples when analyzed by ELISA or PCR. In asymptomatic plants, there was no significant difference in frequency of detection by ELISA between collection methods on each date (replication 1: $\chi^{2}=2.320, \mathrm{df}=1$, $P$ value $=0.20$; replication $2: \chi^{2}=0, \mathrm{df}=$ $1, P$ value $=1)$, or when data were pooled $\left(\chi^{2}=1.941, \mathrm{df}=1, P\right.$ value $\left.=0.1630\right)$. For asymptomatic plants collected on both sampling dates, there were no significant differences in detection frequency between collection methods when assayed by PCR (replication $1: \chi^{2}=2.657, \mathrm{df}=1, P$ value $=$ 0.20 ; replication $2: \chi^{2}=0, \mathrm{df}=1, P$ value $=1$ ). A similar result was obtained when data from the two sampling dates were pooled $\left(\chi^{2}=2.192\right.$, $\mathrm{df}=1, P$ value $=$ 0.1387; Fig. 2). In symptomatic plants, frequency of detection by ELISA using either collection method was not significantly different on each date (replication 1: $\chi^{2}=0.373, \mathrm{df}=1, P$ value $=0.90$; replication 2: $\chi^{2}=2.222$, $\mathrm{df}=1, P$ value $=0.20$ ), or when data were pooled $\left(\chi^{2}=0.201, \mathrm{df}=\right.$ 
$1, P$ value $=0.6539 ;$ Fig. 2$)$. In symptomatic plants tested by PCR, whole-tissue extraction was significantly more sensitive than xylem fluid samples in replication 1 $\left(\chi^{2}=8.765\right.$, df $=1, P$ value $\left.=0.01\right)$ but there was no significant difference in detection frequency between collection methods in replication $2\left(\chi^{2}=2.222\right.$, $\mathrm{df}=$ $1, P$ value $=0.20)$. However, when data were pooled, whole-tissue extraction was significantly more sensitive than xylem fluid samples $\left(\chi^{2}=10.327, \mathrm{df}=1, P\right.$ value $=0.0013)$. There were no significant differences between the ELISA or PCR method of detection in oleander on either collection date (replication 1: $\chi^{2}=0.755$, $\mathrm{df}=1, P$ value $=0.385$; replication $2: \chi^{2}=$ $1, \mathrm{df}=1, P$ value $=1$ ) or when data were pooled $\left(\chi^{2}=0.115\right.$, df $=1, P$ value $=$ 0.734; Table 1).

\section{DISCUSSION}

The use of the Scholander pressure bomb to collect xylem fluid from grapevine improved the ability to detect $X$. fastidiosa by ELISA and PCR. In several cases, $X$. fastidiosa was detected in xylem fluid from asymptomatic plants that was not detected in whole-tissue samples. Although collecting xylem fluid took more time in the field, DNA extraction from xylem fluid in the laboratory was less time consuming than extraction from whole tissue because xylem fluid extraction did not require maceration with a mortar and pestle.

The Scholander pressure bomb allowed xylem fluid to be extracted from grapevine nearly free of phloem fluid and other plant matter. This may improve detection of $X$. fastidiosa in grapevine for several reasons. Xylem fluid extracted with the pressure bomb likely is free of many plant components found in whole-tissue samples that commonly interfere with the DNA extraction process or inhibit PCR. Xylem fluid collection also may aid in the recovery of bacterial DNA during extraction, because far less plant DNA is extracted in this process compared with whole-tissue samples. In addition, X. fastidiosa is a xylemlimited pathogen, so isolation of xylem fluid samples probably improved detection by allowing testing of only the part of the plant that $X$. fastidiosa would be expected to inhabit. Most importantly, X. fastidiosa does not thrive uniformly throughout the xylem; rather, the bacterium is aggregated (1). Using the Scholander pressure bomb enables collection of xylem fluid from 15 to $20 \mathrm{~cm}$ of the shoot terminal, including all attached leaves and petioles, compared with 5 to $10 \mathrm{~cm}$ of tissue used for whole- tissue collection. $X$. fastidiosa is insect transmitted, and insect vectors feed on the tips of growing shoots (27) or the base of actively growing shoots (31) and do not normally feed on hardened tissue. Therefore, the terminal tissue is the most important tissue sample for an early detection system.

Both ELISA and PCR currently are used to detect $X$. fastidiosa in plants. There are advantages and disadvantages to both procedures. Although PCR has been reported to be 100 times more sensitive than ELISA (24), it was not significantly more sensitive in our tests with field plants. Both the $16 \mathrm{~S}$ based primer set used for PCR (24) and the Xylella spp.-specific antibody used for ELISA (33) have been reported to detect most known strains of $X$. fastidiosa. Therefore, similar detection rates probably were not due to strain specificity of PCR and less-specific ELISA detection resulting in positive ELISA tests from other strains of $X$. fastidiosa. Most likely, PCR inhibitors were still present in the extracted DNA,

Table 1. Comparison of the frequency of detection of Xylella fastidiosa in grapevine and oleander tissue using enzyme-linked immunosorbent assay (ELISA) or polymerase chain reaction (PCR) ${ }^{\mathrm{a}}$

\begin{tabular}{lcc}
\hline & \multicolumn{2}{c}{ Samples that tested positive for $\boldsymbol{X}$. fastidiosa } \\
\cline { 2 - 3 } Tissue & ELISA & PCR \\
\hline Grapevine $^{\mathrm{b}}$ & $56 / 120(46.6 \%)$ & $65 / 120(54.2 \%)$ \\
Oleander $^{\mathrm{c}}$ & $39 / 248(15.7 \%)$ & $45 / 248(18.1 \%)$ \\
\hline
\end{tabular}

${ }^{\text {a }}$ Results represent pooled samples from two collection dates.

${ }^{\mathrm{b}}$ Frequencies were not significantly different $\left(\chi^{2}=1.35, \mathrm{df}=1, P\right.$ value $\left.=0.245\right)$.

${ }^{\mathrm{c}}$ Frequencies were not significantly different $\left(\chi^{2}=0.52, \mathrm{df}=1, P\right.$ value $\left.=0.734\right)$.

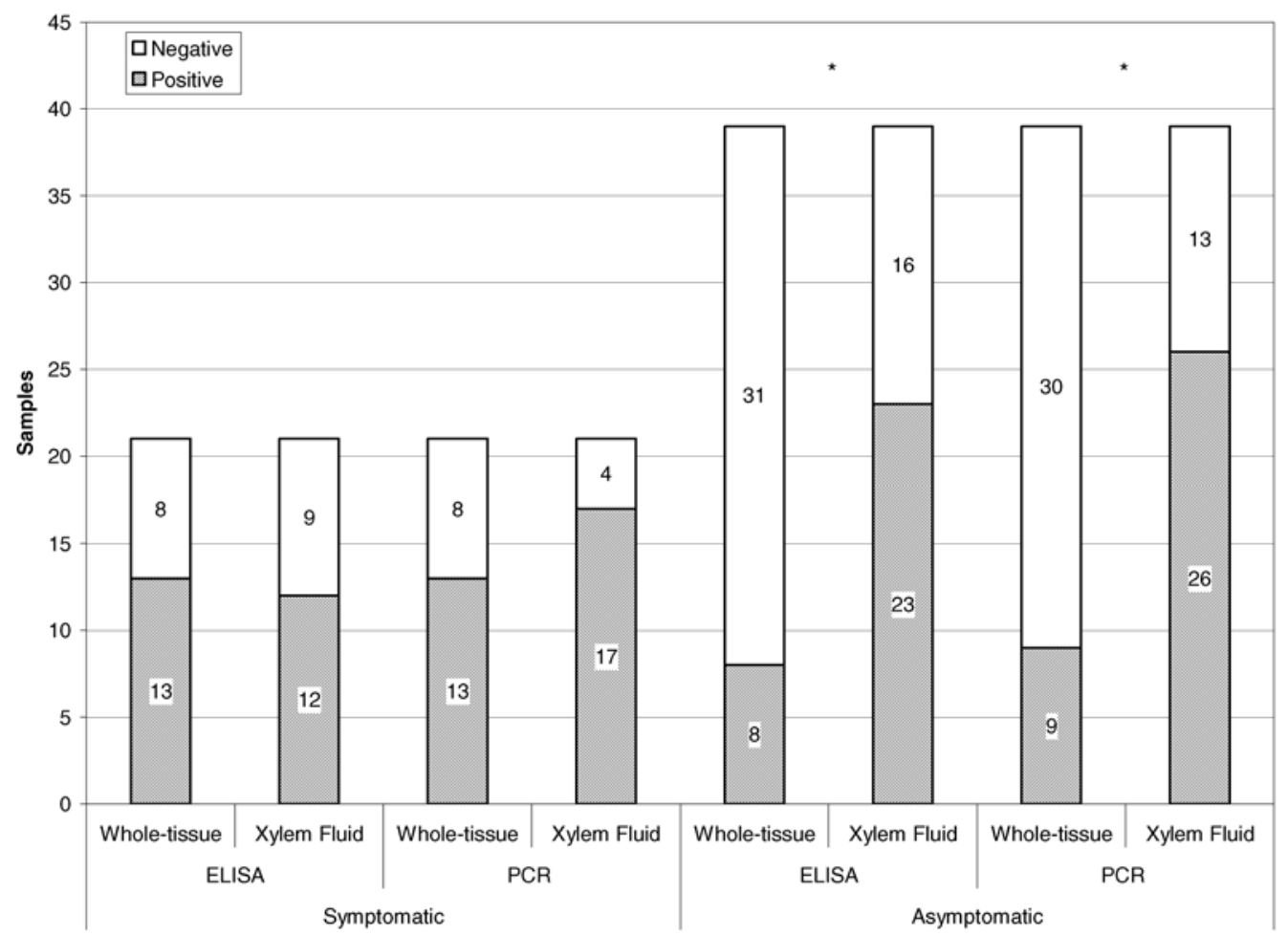

Fig. 1. Comparison of whole-tissue maceration and xylem fluid extraction techniques for detection of Xylella fastidiosa by enzyme-linked immunosorbent assay (ELISA) or polymerase chain reaction (PCR) in symptomatic or asymptomatic grapevine. An asterisk above a pair of vertical bars indicates a statistically significant difference $(P \leq 0.0005)$ in the frequency of positive samples between extraction techniques within symptomatic or asymptomatic tissue samples tested by ELISA or PCR, based on a $\chi^{2}$ analysis. 
regardless of sample collection method, reducing PCR sensitivity to levels comparable with ELISA sensitivity. An advantage of using PCR is that it can be helpful in identifying specific $X$. fastidiosa strains. ELISA is useful because it is a fairly simple procedure and allows detection of the pathogen without requiring expensive equipment, and fewer steps allow fewer chances for error. Xylem fluid collection using the Scholander pressure bomb was amenable to both detection protocols.

In contrast to samples from grapevine, xylem fluid extracted from oleander with the pressure bomb was frothy. This made the collection and measurement of the extracted volume difficult. The froth possibly indicated cell collapse within the stem; therefore, samples collected may not have been pure xylem fluid. Additionally, detection was not improved by collecting samples using the Scholander pressure bomb; therefore, the whole-tissue method of sample collection with ELISA or PCR may be the preferred method for diagnosing $X$. fastidiosa infection in oleander.

Although the Scholander pressure bomb can be a useful tool in the collection of xylem fluid samples, it does have a few drawbacks. If the tissue is too dry, which is often the case in $X$. fastidiosa-infected plants, very little, if any, fluid can be extracted. This problem can cause two complications in testing for $X$. fastidiosa. First, if no xylem fluid sample can be collected, no sample can be tested. In this case, whole-tissue extraction must be done.
Second, if only a small sample of xylem fluid is recovered, the sample may not be representative of the entire section of tissue sampled. In this case, it is a judgment call as to whether a whole-tissue sample would be more beneficial in detecting $X$. fastidiosa. Another complication occurs if the stem is cut or broken. Because the basis of this collection technique depends on the pressurization of the plant tissue to force fluid out of the cut end, any cuts or breaks in the plant matter within the pressure chamber will prevent collection of xylem fluid. Last, because stem samples desiccate, time for xylem fluid collection after removal from the plant is limited. This problem was remedied by taking the portable Scholander pressure bomb to the field for collection or maintaining samples in a moisture chamber for a short period. However, unlike the whole-tissue method, samples cannot be frozen prior to xylem fluid collection.

The intent of this study was to determine if detection of $X$. fastidiosa in plants was improved when xylem fluid samples were collected using the Scholander pressure bomb compared with whole-tissue extraction. Our results indicate that the Scholander pressure bomb is useful for collecting samples for detection of this xylem-limited pathogen in grapevine but not oleander. Although detection of $X$. fastidiosa in oleander was not improved using this new method of sample collection, detection in grapevines was improved using both PCR and ELISA. This tech- nique can be a useful part of pathogen detection by making sample analysis less time consuming, less prone to error, and more sensitive. Furthermore, our study indicated that use of the Scholander pressure bomb may aid in early detection of $X$. fastidiosa in asymptomatic grapevine when the pathogen was not detected using whole-tissue samples. Plant removal prior to disease symptoms will eliminate potential inoculum sources, possibly reducing pathogen spread. In addition to improving the detection of $X$. fastidiosa in grapevines, this method of sample collection may be considered as an option for detection of $X$. fastidiosa in other hosts and other xylemassociated plant pathogens.

\section{ACKNOWLEDGMENTS}

We thank F. Byrne for assistance with the Scholander pressure bomb, C. Gispert and M. Johnson for their help in collecting samples, and M. Blua and H. Costa for review of the manuscript.

\section{LITERATURE CITED}

1. Aldrich, J. H., Gould, A. B., and Martin, F. G. 1992. Distribution of Xylella fastidiosa within roots of peach. Plant Dis. 76:885-888.

2. Banks, D., Albibi, R., Chen, J., Jarret, R., Lamikanra, O., and Smith, B. 1998. Specific detection of Xylella fastidiosa Pierce. (Abstr.) Phytopathology. 88:S5.

3. Bazzi, C., Zaccardelli, M., and Niepold, F. 1994. Monospecific antiserum is suitable for the selective detection of Xylella fastidiosa. Microbiol. Res. 149:337-341.

4. Bell, C. R., Dickie, G. A., Harvey, W. L. G., and Chan, J. W. Y. F. 1995. Endophytic bacteria in grapevine. Can. J. Microbiol. 41:46-53.

5. Bextine, B. R., Wayadande, A., Bruton, B. D.,

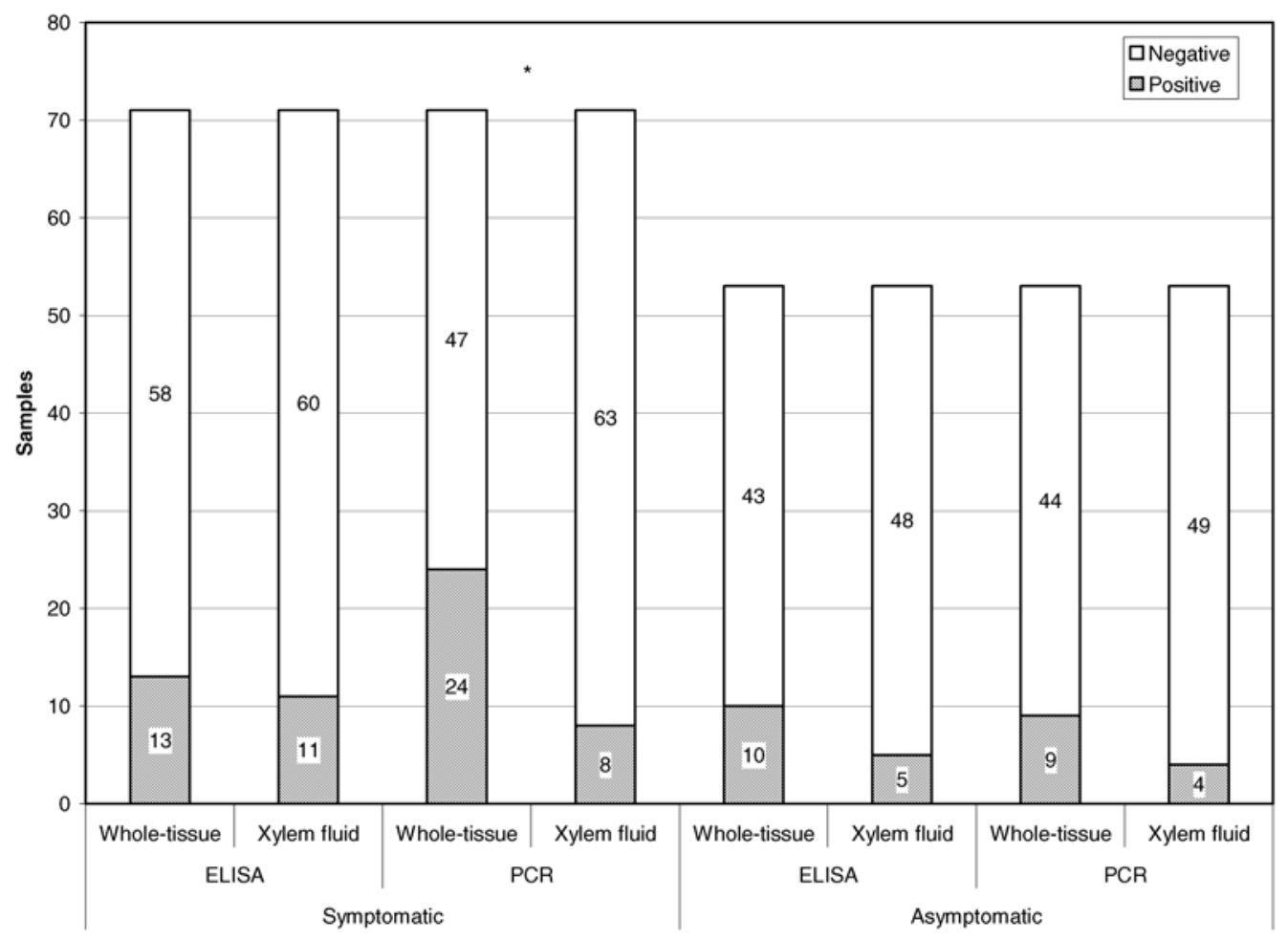

Fig. 2. Comparison of whole-tissue maceration and xylem fluid extraction techniques for detection of Xylella fastidiosa by enzyme-linked immunosorbent assay (ELISA) or polymerase chain reaction (PCR) in symptomatic or asymptomatic oleander. An asterisk above a pair of vertical bars indicates a statistically significant difference $(P \leq 0.0005)$ in the frequency of positive samples between extraction techniques within symptomatic or asymptomatic tissue samples tested by ELISA or PCR, based on a $\chi^{2}$ analysis. 
Pair, S. D., Mitchell, F., and Fletcher, J. 2001. Effect of insect exclusion on the incidence of yellow vine disease and of the associated bacterium in squash. Plant Dis. 85:875-878.

6. Chang, C. J., Garnier, M., Zreik, L., Rossetti, V., and Bové, J. M. 1993. Culture and serological detection of the xylem-limited bacterium causing citrus variegated chlorosis and its identification as a strain of Xylella fastidiosa. Curr. Microbiol. 27:137-142.

7. Chen, J., Banks, D., Jarret, R. L., Newman, M., Chang, C. J., and Smith, B. J. 1999. Using 16S rDNA sequences to identify Xylella fastidiosa. (Abstr.) Phytopathology 89:S15.

8. Chen, J., Jarret, R. L., Qin, X., Hartung, J. S., Banks, D., Chang, C. J., and Hopkins, D. L. 2000. 16S rDNA sequence analysis of Xylella fastidiosa strains. Syst. Appl. Microbiol. 23:349-354.

9. Costa, H. S., Blua, M. J., Bethke, J. A., and Redak, R. A. 2000. Transmission of Xylella fastidiosa to oleander by the glassy-winged sharpshooter, Homalodisca coagulata. Hortscience 35:1265-1267.

10. Davis, M. J., French, W. J., and Schaad, N. W. 1981. Axenic culture of the bacteria associated with phony disease of peach and plum leaf scald. Curr. Microbiol. 6:309-314.

11. Davis, M. J., Purcell, A. H., and Thomson, S. V. 1978. Pierce's disease of grapevines: Isolation of the causal bacterium. Science (Wash. D. C.). 199:75-77.

12. Davis, M. J., Purcell, A. H., and Thomson, S. V. 1980. Isolation media for the Pierce's disease bacterium. Phytopathology 70:425-429.

13. Della Coletta-Filho, H., Takita, M. A., de Souza, A. P., Aguilar-Vildoso, C. I., and Machado, M. A. 2001. Differentiation of strains of Xylella fastidiosa by a variable number of tandem repeat analysis. Appl. Environ. Microbiol. 67:4091-4095.

14. Ferreira, H., Neto, J. R., Goncalves, E. R., and Rosato, Y. B. 1999. A simplified subtractive hybridization protocol used to isolate DNA sequences specific to Xylella fastidiosa. Microbiology (Read.) 145:1967-1975.

15. Freitag, J. H. 1951. Host range of the Pierce's disease virus of grapes as determined by insect transmission. Phytopathology 41:920-934.

16. Frohme, M., Camargo, A. A., Heber, S., Czink, C., Simpson, A. J. D., Hioheisel, J. D., and de Souza, A. P. 2000. Mapping analysis of the $X y$ lella fastidiosa genome. Nucleic Acids Res. 28:3100-3104.

17. Hallmann, J., Kloepper, J. W., and RodriguezKabana, R. 1997. Application of the Scholander pressure bomb to studies on endophytic bacteria of plants. Can. J. Microbiol. 43:411-416.

18. Hill, B. L., and Purcell, A. H. 1995. Multiplication and movement of Xylella fastidiosa within grapevine and four other plants. Phytopathology 85:1368-1372.

19. Hopkins, D. L. 1989. Xylella fastidiosa: Xylem-limited bacterial pathogen of plants. Annu. Rev. Phytopathol. 27: 271-290.

20. Leu, H. H., Leu, L. S., and Lin, C. P. 1998. Development and application of monoclonal antibodies against Xylella fastidiosa, the causal bacterium of pear leaf scorch. J. Phytopathol. (Berl.) 146:31-37.

21. Li, W. B., Zreik, L., Fernandes, N. G., Miranda, V. S., Teixeira, D. C., Ayres, A. J., Garnier, M., and Bové, J. M. 1999. A triply cloned strain of Xylella fastidiosa multiplies and induces symptoms of citrus variegated chlorosis in sweet orange. Curr. Microbiol. 39:106-108.

22. McElrone, A. J., Sherald, J. L., and Pooler, M. R. 1999. Identification of alternative hosts of Xylella fastidiosa in the Washington, D.C. area using nested polymerase chain reaction (PCR). J. Arboric. 25:258-263

23. Minsavage, G. V., Hopkins, D. L., Leite, R. M. V. B. C., and Stall, R. E. 1993. Comparison of PCR amplification of DNA and ELISA for the detection of Xylella fastidiosa in plant extracts. (Abstr.) Phytopathology 83:1399.

24. Minsavage, G. V., Thompson, C. M., Hopkins, D. L., Leite, R. M. V. B. C., and Stall, R. E. 1994. Development of a polymerase chain reaction protocol for detection of Xylella fastidiosa in plant tissue. Phytopathology 84:456461.
25. Pooler, M. R., and Hartung, J. S. 1995. Specific PCR detection and identification of $X y$ lella fastidiosa strains causing citrus variegated chlorosis. Curr. Microbiol. 31:377-381.

26. Pooler, M. R., Myung, I. S., Bentz, J., Sherald, J., and Hartung, J. S. 1997. Detection of $X y$ lella fastidiosa in potential insect vectors by immunomagnetic separation and nested polymerase chain reaction. Lett. Appl. Microbiol. 25:123-126.

27. Purcell, A. H. 1975. Role of the blue-green sharpshooter, Hordnia circellata, in the epidemiology of Pierce's disease of grapevines. Environ. Entomol. 4:745-752.

28. Purcell, A. H. 1997. Xylella fastidiosa, a regional problem or global threat? J. Plant Pathol. 79:99-105.

29. Purcell, A. H., and Finlay, A. H. 1979. Acquisition and transmission of bacteria through artificial membranes by leafhopper vectors of Pierce's disease. Entomol. Exp. Appl. 25:188 195.

30. Purcell, A. H., and Hopkins, D. L. 1996. Fastidious xylem-limited bacterial plant pathogens. Annu. Rev. Phytopathol. 34:131-151.

31. Purcell, A. H., and Saunders, S. R. 1999. Glassy-winged sharpshooter expected to increase plant disease. Calif. Agric. 53:26-27.

32. Purcell, A. H., Saunders, S. R., Hendson, M Grebus, M. E., and Henry, M. J. 1999. Causal role of Xylella fastidiosa in oleander leaf scorch disease. Phytopathology 89:53-58.

33. Sherald, J. L., and Lei, J. D. 1991. Evaluation of rapid ELISA test kit for detection of Xylella fastidiosa in landscape trees. Plant Dis. 75:200-203.

34. Smart, C. D., Hendson, M., Guilhabert, M. R. Saunders, S., Friebertshauser, G., Purcell, A. H., and Kirkpatrick, B. C. 1998. Seasonal detection of Xylella fastidiosa in grapevines with culture, ELISA and PCR. (Abstr.) Phytopathology 88:S83.

35. Zhang, Y. P., Uyemoto, J. K., and Kirkpatrick, B. C. 1998. A small-scale procedure for extracting nucleic acids from woody plants infected with various phytopathogens for PCR assay. J. Virol. Methods 71:45-50. 